\title{
OPEN A DNA barcode-based survey of wild urban bees in the Loire Valley, France
}

\author{
Irene Villalta ${ }^{1 凶}$, Romain Ledet ${ }^{2}$, Mathilde Baude ${ }^{2}$, David Genoud ${ }^{3}$, Christophe Bouget ${ }^{4}$, \\ Maxime Cornillon $^{5}$, Sébastien Moreau ${ }^{1}$, Béatrice Courtial ${ }^{6} \&$ Carlos Lopez-Vaamonde ${ }^{1,6}$
}

The current decline of wild bees puts important ecosystem services such as pollination at risk. Both inventory and monitoring programs are needed to understand the causes of wild bee decline. Effective insect monitoring relies on both mass-trapping methods coupled with rapid and accurate identifications. Identifying wild bees using only morphology can be challenging, in particular, specimens from mass-trapped samples which are often in poor condition. We generated DNA barcodes for 2931 specimens representing 157 species (156 named and one unnamed species) and 28 genera. Automated cluster delineation reveals 172 BINs (Barcodes Index Numbers). A total of 36 species (22.93\%) were found in highly urbanized areas. The majority of specimens, representing $96.17 \%$ of the species barcoded form reciprocally exclusive groups, allowing their unambiguous identification. This includes several closely related species notoriously difficult to identify. A total of 137 species (87.26\%) show a "one-to-one" match between a named species and the BIN assignment. Fourteen species (8.92\%) show deep conspecific lineages with no apparent morphological differentiation. Only two species pairs shared the same BIN making their identification with DNA barcodes alone uncertain. Therefore, our DNA barcoding reference library allows reliable identification by non-experts for the vast majority of wild bee species in the Loire Valley.

Long-term monitoring programs have documented a sharp decline of insects ${ }^{1-5}$. The loss of insect pollinators is particularly worrying because of its potential negative ecological and economic consequences ${ }^{6-8}$. Land use change has been shown to be a major factor involved in the loss of worldwide pollinator populations ${ }^{9}$. Indeed, intensive agriculture has led to the loss of ecological niches for a number of pollinator species, to which are added the adverse effects of pesticide uses ${ }^{10}$. Through the expansion of impervious surfaces, urbanization is also associated with pollinator decline $\mathrm{e}^{11,12}$, although some urban green areas such as residential and community gardens, if properly managed, can constitute important refuges for wild bees ${ }^{13-15}$. This factor and the higher temperatures associated with rapid global warming are accelerating the decline of pollinators worldwide ${ }^{16,17}$. This scenario has fostered the idea of considering urban areas as potential refuges for pollinators ${ }^{18,19}$. Consequently, a growing number of studies on urban ecology have emerged describing population dynamics of wild bees in urban areas ${ }^{19,20}$ due to their pivotal importance. In addition, citizen science has been successfully shown to be an efficient way of monitoring urban bees ${ }^{21-24}$. However, the accurate identification at species level for several bee genera requires advanced taxonomic knowledge, which is limited to a few experts or even not available in many countries. This taxonomic impediment is slowly being overcome through the use of traditional DNA barcoding ${ }^{25-28}$ or more recently developed high-throughput DNA barcoding ${ }^{29-33}$. Indeed, cox1 (cytochrome $c$ oxidase subunit I gene) barcodes have been shown to distinguish between bees difficult to identify due to minor morphological differences ${ }^{34-36}$ or even cryptic bee species ${ }^{37}$.

The accuracy of DNA-based identifications depends on the completeness of DNA barcoding reference libraries. However, only a few DNA barcode reference libraries have been developed for wild bee national faunas, including Ireland ${ }^{38}$; Germany ${ }^{27}$, Canada ${ }^{25,39}$ and Chile $^{28}$ as well as some regional faunas ${ }^{26,40,41}$. In addition, identification accuracy depends also on the complete characterization of intraspecific variability $42-44$.

France has a rich wild bee fauna with over 955 species recorded ${ }^{45}$, for the whole country but relatively few DNA barcodes of French bees have been published ${ }^{46-48}$. Our study is the first major contribution to establish a DNA barcoding reference library for French wild bees.

${ }^{1}$ IRBI, UMR 7261, CNRS, Université de Tours, Tours, France. ${ }^{2}$ INRAE USC 1328, LBLGC EA 1207, Université d'Orléans, Orléans, France. ${ }^{3}$ Domaine Bellevue 2, Arzens, France. ${ }^{4}$ INRAE, UR EFNO, Nogent-sur-Vernisson, France. ${ }^{5} \mathrm{CETU}$ Innophyt, Université de Tours, Tours, France. ${ }^{6}$ INRAE, URZF, Orléans, France. ${ }^{\square}$ email: irenevillaltaalonso@gmail.com 

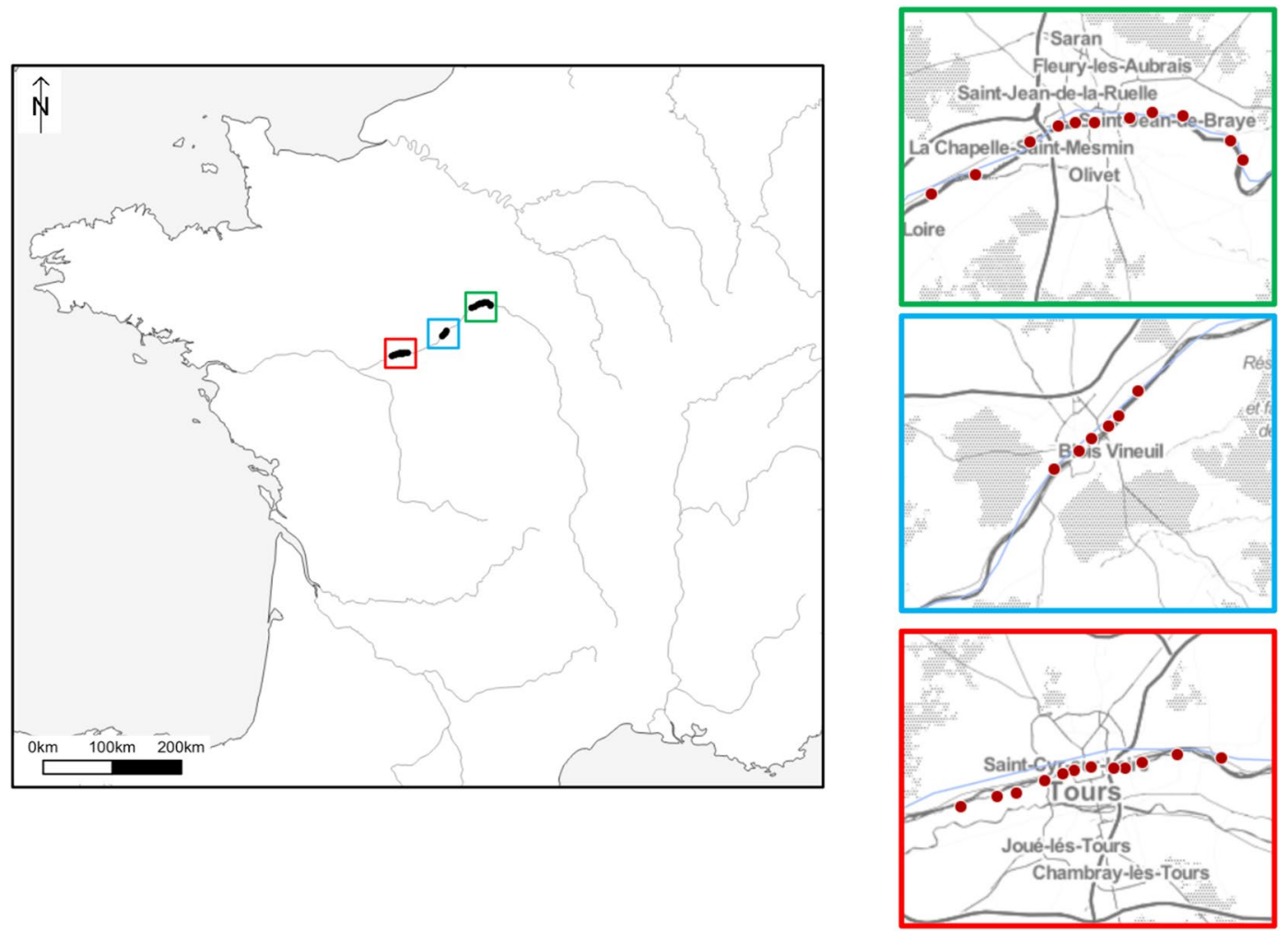

Figure 1. Map locations for all sampling from the three main regions in the Loire Valley. The software QGIS v.3.8 was used to represent sampling sites (http://www.qgis.org).

We focused our sampling in central France, a region where over 180 species of bees have been recorded (unpublished data, Christian Cocquempot personal communication, 2020). Here we present 2931 barcodes of 157 wild bee species collected at 29 urban and peri-urban sites in three major cities along the Loire Valley.

\section{Results}

Taxon sampling and DNA sequencing success. A total of 3532 bee specimens were collected over the 2 years of survey; 3057 bees were collected with pan-traps and 475 were collected along transects in 29 sites located in three French cities (Tours, Orléans and Blois) (Fig. 1, Table S1).

Of the 3532 specimens collected 2931 were successfully barcoded (82.98\%) (Table S2). The overall success rate varied depending on the sequencing method, Sanger versus Single-Molecule Real-Time sequencing $\left(\mathrm{SMRT}^{49}\right)$ and the primers used. Out of the 252 samples analysed by Sanger sequencing, we obtained a higher barcoding success rate using newly designed primers (133 sequences out of 188 specimens, i.e. $70.74 \%$ ) (Table S3) than with the traditional Folmer primers (15 sequences out of 64 specimens, i.e. 23.43\%). We obtained full DNA barcodes for 13 species whereas six species were represented only by short sequences ( $\geq 300 \mathrm{bp}$ and $<500 \mathrm{bp}$ ). Twenty-seven out of 148 sequences were less than 500 bp long. Of the 3350 specimens processed using PacBio Sequel platform (Pacific Biosciences, Menlo Park, CA, USA) by SMRT sequencing, 2783 specimens (83.07\%) yielded a barcode sequence $>300 \mathrm{bp}$. Six out of 2783 were less than $500 \mathrm{bp}$. No barcodes could be obtained for 410 additional samples and 157 samples (4.69\%) appeared to be cross contaminated. Sequencing failure was not homogeneous across families, and a few species presented greater amplification problems, especially among the genera Andrena, Hylaeus and Dasypoda.

Species identification and BIN assignment. Our integrative analyses combining morphology and DNA barcodes, identified a total of 157 species out of which 156 are described valid species belonging to six families (Andrenidae, Apidae, Colletidae, Halictidae, Megachilidae, Melittidae) and 28 genera (Tables 1, S4, Fig. 2). In addition, we found one specimen (MB00149) of an unnamed Andrena species whose BIN was new to BOLD. Seventy species (44.6\%) found in our study had not been reported before within the available regional species inventories. For instance, our barcode of Andrena avara liturata (Warncke) represent a first record for the studied area, and a new BIN in BOLD (Barcode of Life Data).

Of the 157 species 156 were assigned to 172 BINs (results on 25 September 2020), sixteen (9.30\%) of them were new to BOLD. Only one of the 157 species barcoded, did not have a BIN assigned, since its barcode was shorter than $500 \mathrm{bp}^{50}$.

Out of the 157 species barcoded from our studied area 137 (87.26\%) had already been barcoded from Germany (Table S4). 


\begin{tabular}{|l|l|l|l|}
\hline Family & Barcoded records & Genera & Species \\
\hline Andrenidae & 430 & 2 & 38 \\
\hline Apidae & 579 & 8 & 29 \\
\hline Colletidae & 44 & 2 & 15 \\
\hline Halictidae & 1766 & 4 & 47 \\
\hline Megachilidae & 69 & 9 & 23 \\
\hline Melittidae & 43 & 3 & 5 \\
\hline Total & 2931 & 28 & 157 \\
\hline
\end{tabular}

Table 1. Number of barcoded records, genera and species collected for the six bee families in our sampling.

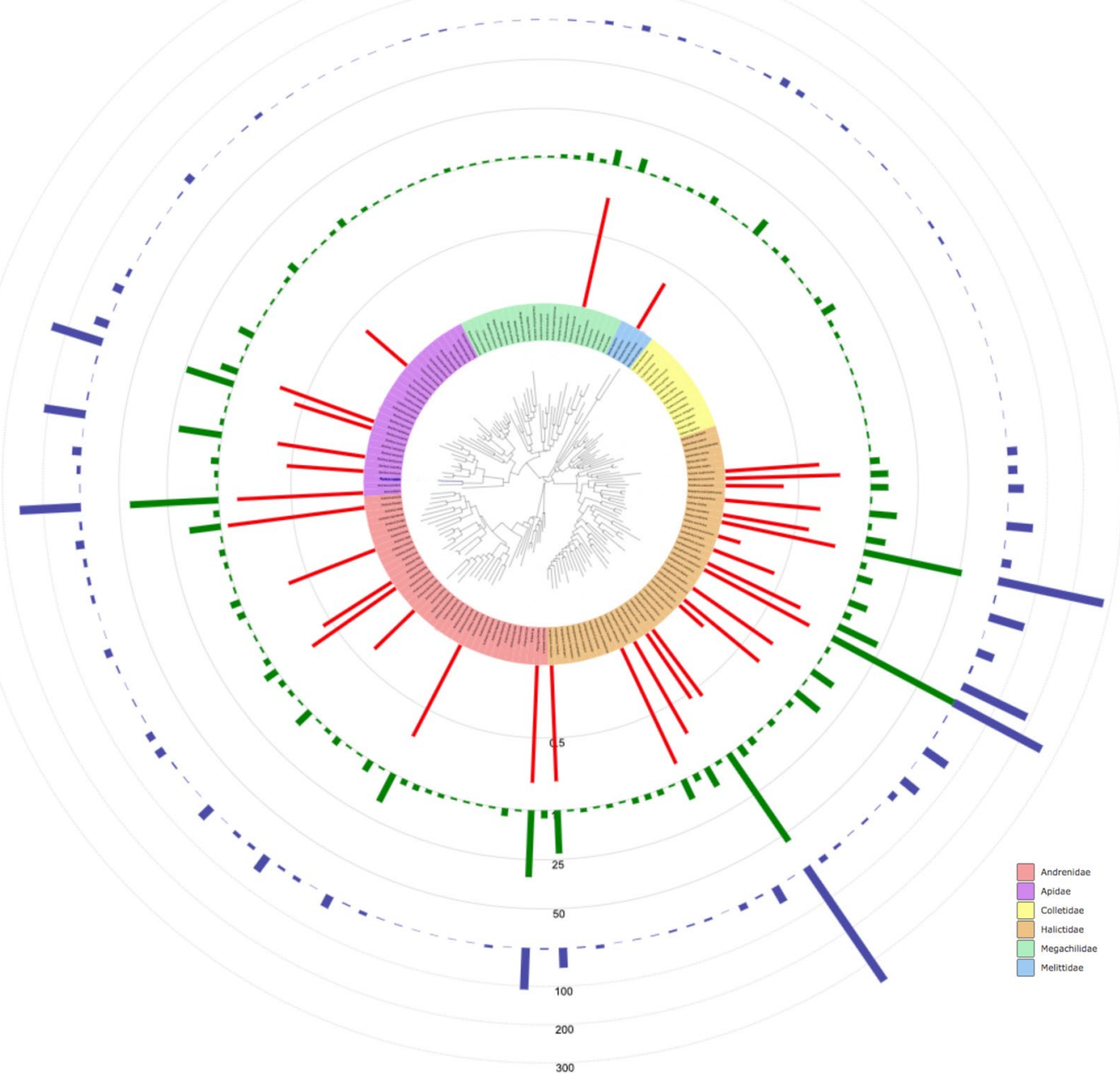

Figure 2. Approximately Maximum-Likelihood tree of species found in our study. Species are color-coded by family. Bars represent the abundance of each species (blue), the number of haplotypes (green) and the values of haplotype diversity only for species with $n>10$ (red).

A total of 36 species (22.93\%) were found in highly urbanized areas (i.e. city centers).

Halictidae accounted for most of the specimens, representing just over $60 \%$ of the total specimens collected and $14.3 \%$ of genera. The most diverse families in terms of number species were Halictidae and Andrenidae, accounting for $30 \%$ and $24 \%$ of species, respectively. Only five species (3.18\%) of Melittidae were observed (Tables 1, S4). 


\begin{tabular}{|l|l|l|l|l|}
\hline Family & Species & Author & N & BIN name (N specimens per BIN) \\
\hline Andrenidae & Andrena bicolor & Fabricius, 1775 & 7 & $\begin{array}{l}\text { BOLD:AAD0134(5) } \\
\text { BOLD:AAD0135(1) }\end{array}$ \\
\hline Andrenidae & Andrena helvola & Linnaeus, 1758 & 19 & $\begin{array}{l}\text { BOLD:ABU9089(1) } \\
\text { BOLD:ACY0380(7) } \\
\text { BOLD:ADZ3664(11) }\end{array}$ \\
\hline Andrenidae & Andrena lagopus & Latreille, 1809 & 2 & $\begin{array}{l}\text { BOLD:AAK0222(1) } \\
\text { BOLD:ACC2245(1) }\end{array}$ \\
\hline Andrenidae & Panurgus calcaratus & Scopoli, 1763 & 4 & $\begin{array}{l}\text { BOLD:AAE3229(3) } \\
\text { BOLD:AED3388(1) }\end{array}$ \\
\hline Apidae & Anthophora plumipes & Pallas, 1772 & 10 & $\begin{array}{l}\text { BOLD:AAF1671(2) } \\
\text { BOLD:AAF1672(7) } \\
\text { BOLD:AAZ7403(1) }\end{array}$ \\
\hline Halictidae & Halictus langobardicus & Blüthgen, 1944 & 69 & $\begin{array}{l}\text { BOLD:AAD5869(68) } \\
\text { BOLD:ACE9465(1) }\end{array}$ \\
\hline Halictidae & Halictus maculatus & Smith, 1848 & 25 & $\begin{array}{l}\text { BOLD:AAY5383(22) } \\
\text { BOLD:ACH4344(3) }\end{array}$ \\
\hline Halictidae & Lasioglossum laticeps & Schenck, 1868 & 51 & $\begin{array}{l}\text { BOLD:AAY5433(46) } \\
\text { BOLD:ADZ4826(1) } \\
\text { BOLD:ADZ6624(2) }\end{array}$ \\
\hline Halictidae & Lasioglossum minutissimum & Kirby, 1802 & 5 & $\begin{array}{l}\text { BOLD:AAI1289(1) } \\
\text { BOLD:ACQ8646(4) }\end{array}$ \\
\hline Halictidae & Lasioglossum subhirtum & Lepeletier, 1841 & 3 & $\begin{array}{l}\text { BOLD:ADM2541(2) } \\
\text { BOLD:ADZ3360(1) }\end{array}$ \\
\hline Halictidae & Lasioglossum villosulum & Kirby, 1802 & 52 & $\begin{array}{l}\text { BOLD:AAC2460(5) } \\
\text { BOLD:AAC2461(46) } \\
\text { BOLD:AEC1752(1) }\end{array}$ \\
\hline Halictidae & Lasioglossum zonulum & Smith, 1848 & 46 & $\begin{array}{l}\text { BOLD:AAB3147(41) } \\
\text { BOLD:AAB3148(5) }\end{array}$ \\
\hline Megachilidae & Osmia bicornis & Linnaeus, 1758 & 8 & $\begin{array}{l}\text { BOLD:AAD6282(7) } \\
\text { BOLD:ADZ8010(1) }\end{array}$ \\
\hline Melittidae & Dasypoda hirtipes & Fabricius, 1793 & 20 & $\begin{array}{l}\text { BOLD:AAI9629(19) } \\
\text { BOLD:AEC2767(1) }\end{array}$ \\
\hline
\end{tabular}

Table 2. Sampled bee species barcodes assigned to multiple BINs by the BOLD system database.

\begin{tabular}{|l|l|l|l|l|l|l|l|}
\hline Label & $\mathbf{n}$ & Taxa & Comparisons & Min Dist (\%) & Mean Dist (\%) & Max Dist (\%) & SE Dist (\%) \\
\hline Within Species & 2883 & 109 & 210,415 & 0.00 & 0.23 & 9.81 & 0.00 \\
\hline Within Genus & 2753 & 20 & 836,587 & 1.24 & 15.70 & 50.00 & 0.00 \\
\hline Within Family & 2931 & 6 & 775,254 & 8.56 & 18.12 & 34.38 & 0.00 \\
\hline
\end{tabular}

Table 3. Kimura 2 Parameter sequence divergence between barcode sequences at the species, genus and family level.

The majority of species (96.17\%) had their own unique BIN or were assigned to several BINs that formed single clades allowing unambiguous identification based on DNA barcodes; 48 species were represented by a single record. The number of specimens sequenced per BIN ranged from 1 to 360 (for Lasioglossum morio (Fabricius)), averaging 17 specimens per BIN. Sixty-one BINs were represented by a single individual (singletons).

Multiple BINS were associated with 14 species, with up to three BINS for some, including Andrena helvola (Linnaeus), Anthophora plumipes (Pallas), Lasioglossum laticeps (Schenck) and L. villosulum (Kirby) (Tables 2, S4).

Two species pairs share the same BIN: Andrena carantonica (Pérez) and A. trimmerana (Kirby) (BOLD:AAD2472) and Halictus simplex (Blüthgen) and H. langobardicus (Blüthgen) (BOLD:AAD5869). The identification of those four species based on DNA barcode data is therefore uncertain. One species barcoded in our study (Lasioglossum mediterraneum (Blüthgen)) was new to BOLD but the sequence was too short to have a BIN assigned. In addition, one unidentified individual in the genus Andrena (MB00149) was assigned to a new BIN (BOLD:ADZ3755) to BOLD. This new BIN remains without species identification pending of collection and analysis of more individuals.

Barcode gap and haplotype diversity. The average genetic distance within species and genera in the dataset were $0.23 \%$ and $15.70 \%$ respectively (Table 3 ) with a maximum intraspecific distance of $9.81 \%$ for Andrena lagopus (Table S4, Fig. 3a). Intraspecific barcode divergence averaged $0.23 \%$ whereas distance to the nearest-neighbour species averaged $9.08 \%$. When we considered only species with a number of records $\mathrm{n} \geq 3$, intraspecific divergence exceeded $2 \%$ in three species; Panurgus calcaratus (Scopoli) (2 BINs), Andrena bicolor (Fabricius) (2 BINs) and Andrena helvola (Linnaeus) (3 BINs) (Table S4, Fig. 3b). 
a)

Pairwise distance

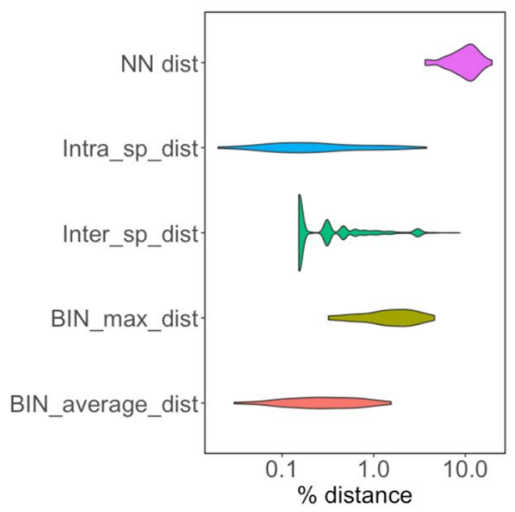

c) Maximal intraspecific vs nearest neighbour

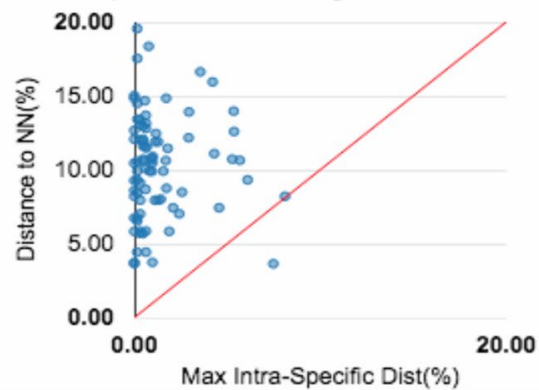

b)

Mean intraspecific vs nearest neighbour

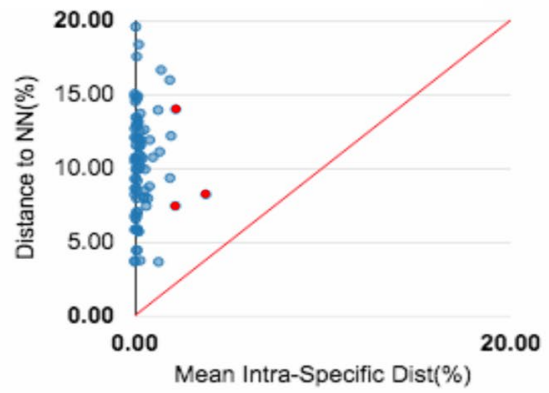

d)

Individuals per species vs maximal intraspecific

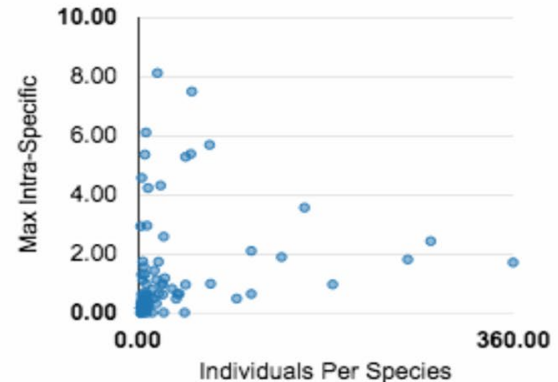

Figure 3. Kimura 2 Parameter distances for species with a number of records $n \geq 3$. (a) Violin plot representing Nearest-neighbor (NN), Mean Intra and Inter specific genetic distances and BIN maximal and average distances; (b) Mean intra-specific distances vs the minimum inter-specific distances, species with intra-specific distances over $2 \%$ are depicted in red; (c) Maximal intra-specific distances $v s$. the minimum inter-specific distances; (d) Number of individuals in each species against their max intra-specific distances.

The mean intraspecific distance $(n \geq 3)$ distribution ranged from 0 to $3.78 \%$ and overlapped slightly with the distance to the nearest neighbour distribution (3.64-19.56\%) (Fig. 3a,b). However, nearest-neighbour distances were on average more than tenfold higher than maximum intraspecific distances (Fig. 3a,c). Lasioglossum villosulum maximum intraspecific distance values were higher than their nearest-neighbour distance. Conversely, K2P distances to the nearest neighbour $<2 \%$ were obtained for two species pairs: Andrena trimmerana/A. carantonica and Halictus langobardicus/H. simplex (Table S4). Maximum intraspecific divergence was not correlated with the number of individuals sampled per species $(R=0.174, P=0.113$ (Fig. $3 \mathrm{~d}$ ).

Our data set contained 787 unique haplotypes with an average of five haplotypes per species and a maximum of 70 haplotypes for Lasioglossum malachurum (Kirby). We found variable patterns of haplotype diversity among the species (Table S4). The number of haplotypes per species ranged from one to 70, and the values of haplotype diversity from 0 to 0.95 . Andrena flavipes (Panzer) had the highest haplotype diversity value, followed by Lasioglossum sabulosum (Warncke), Apis mellifera (Linnaeus) and Lasioglossum malachurum (Table S4). When we considered species with more than ten individuals, the number of samples collected per species was highly correlated with the number of haplotypes found $(\mathrm{R}=0.898, \mathrm{P}=1.114 \mathrm{e}-13)$, but not with the values of haplotype diversity $(\mathrm{R}=0.228, \mathrm{P}=0.181)$ (Fig. 2).

\section{Discussion}

DNA barcoding allows the unambiguous identification of over $96.17 \%$ of the wild bee species found in our study. Among them species that are notoriously difficult to identify morphologically like: Bombus terrestris/ lucorum complex ${ }^{51}$.

Our barcode analysis revealed one interesting Andrena individual collected in the national reserve of Saint Mesmin, which was assigned to a BIN new to BOLD, and remains unnamed at the species level. By sequence homology, this individual belongs to the 'Andrena bicolor' group, and its nearest neighbour is Andrena allosa (Warncke). The Andrena bicolor species group has been recently revised to clarify the status of several alpine species $^{52}$, the results suggest the existence of a substantial cryptic diversity in southern European Andrena (Euandrena). In the present study in parallel to the new BIN attributed to this specimen (BOLD:ADZ3755), BINs BOLD:AAD0134 and BOLD:AAD0135 are also from the 'Andrena bicolor' group. Considering that two of these three BINs are represented by only one individual is very difficult to morphologically determine if these BINs 
represent different species or if they are representatives of subspecies of the 'Andrena bicolor' group that are not well represented so far in the BOLD database. Our specimen could indeed represent a new species or subspecies within this cryptic complex, but more specimens are needed to assess its taxonomic status.

The two species pairs that shared a BIN Andrena trimmerana/A. carantonica and Halictus langobardicus/H. simplex are morphologically very similar. Indeed, females of Halictus simplex/langobardicus/compressus complex are morphologically indistinguishable ${ }^{53}$. Similarly, females of both Andrena carantonica and A. trimmerana show no morphological differentiation. The BIN shared by both Andrena carantonica and A. trimmerana also contains specimens of A. scotica (Perkins) and A. spinigera (Kirbi). A taxonomic revision of these species is needed to clarify their status within Andrena. The morphological identification of specimens of these difficult groups must be done by expert taxonomists with access to reference collections including types, and comparing specimens from several geographical origins.

More than half of the bees sampled in our study, and includes the most abundant species, belong to the Halictidae (Table 1, Fig. 2). Other studies have reported similar results with halictid bees representing the dominant group between 52.7 and $98.7 \%$ of records sampled in different countries and habitats ${ }^{54-60}$. Halictidae has also been the most abundant family in bee monitoring studies of other French cities ${ }^{11,12,61}$. Pan-trapping has previously been associated with an excessive catching of halictids compared to other families collected ${ }^{62}$. Although we have complemented our sampling with netting, the taxonomic overrepresentation of our sampling towards halictids (that are ground nesting bees) is likely to be caused by pan-trapping.

Sequencing failure for some bee taxa has been reported especially among Andrena ${ }^{38}$ and Hylaeus species ${ }^{63}$. They have been attributed with inefficient primer annealing in the case of Andrena and with the presence of heteroplasmy for Hylaeus species ${ }^{63}$. We have sequenced only a few samples with Sanger sequencing methods, and individuals that failed to amplify the barcode sequence were repeated by SMRT sequencing methods. SMRT barcoding methodology eliminates the potential sequencing issues associated with the amplification of multiple mitochondrial copies or with the amplification of nuclear mitochondrial pseudogenes (numts). However, the presence of numts could contribute to failures in sequencing or the sequencing of contaminants. Sampling, storage conditions and DNA extraction methods can be at the origin of a number of sequencing problems ${ }^{64}$. Our pan-trapping involved bees being kept in soapy water for up to 4 days. This could favour DNA degradation and cross-contamination of samples affecting the rate of DNA sequencing success (82\%) compared to the results obtained on DNA amplification of swept individuals (90\%).

Our data shows a marked difference between mean intraspecific $(0.23 \%)$ and interspecific (15.70\%) genetic divergence indicating the existence of a species barcode gap ${ }^{65}$ in our dataset (Table 3 ). This low average intraspecific divergence has also been reported in Canadian wild bees ${ }^{26}$.

Here we report an $83.07 \%$ success rate using SMRT sequencing compared to $70.74 \%$ with Sanger sequencing using our newly designed primers. Sanger sequencing remains the gold standard in terms of quality and reliability for small projects of a few hundred samples. However, Sequel platform can greatly reduce sequencing costs and be more competitive for projects with thousands of samples ${ }^{49}$.

Our analyses revealed 14 species (9\%) with multiple BINs (Table 2). A barcoding study on German bees found a similar level (11\%) of species with multiple BINs ${ }^{27}$. Among the 14 species that show deep mitochondrial splits, most belonged to Andrena ( 3 spp.) and Lasioglossum (5 spp.), the latter being the most species-rich genus of bees worldwide ${ }^{66}$. The identification of Andrena species is considered challenging due to the great diversity of the genus and the complex Andrena subgeneric keys ${ }^{67,68}$, which makes the identification of species represented by single individuals very difficult. Cases of cryptic diversity and/or deep intraspecific divergences have been suggested for this genus ${ }^{52}$ and the taxonomic status of several species remains uncertain ${ }^{27,69}$.

We have reported five new BINS within the Lasioglossum genus. Lasioglossum is considered morphologically homogeneous and relatively difficult to identify ${ }^{35,70,71}$. Our study has found three BINs within the Lasioglossum villosulum complex. The species complex formed up to five BINS has been the subject of a recent taxonomic revision ${ }^{72}$ which has resurrected Lasioglossum medinai (Vachal) and L. berberum (Benoist). The higher values of maximum intra-specific distances compared to the distance to the nearest neighbour suggest the existence of cryptic diversity for the species complex.

A genomic approach ${ }^{41,73}$ is necessary to further investigate the deep intraspecific DNA barcode splits (Table 2) observed in our study.

The French wild bee fauna has a high overlap with the German fauna specially for central European species. However, most of the Mediterranean wild bee fauna remains to be barcoded. We have found a relatively high species richness of bees in urban areas with 36 species occurring in city centers. Other studies have also found similar levels of species richness in highly urbanized areas ${ }^{20}$. In the periurban areas we found a richer community of wild bees, one particularly interesting species we found is Megachile genalis (Morawitz), which occurs in marshy meadows rich in both Carduus and Cirsium (Asteraceae) plants. It nests in the stems of those plants and feeding preferentially on Asteraceae as well as other plants with wide stems such as Oenanthe and Angelica (Apiaceae).

Our studied fauna of the Loire Valley being in central France has few Mediterranean species and therefore a high overlap with that of Germany $(87.26 \%)$. Although many of the species occurring in the Loire valley are already barcoded from Germany the French barcodes will help to fully characterize the intraspecific variability of European wild bees.

\section{Conclusion}

Our DNA-based survey represents a major contribution to the barcoding of European wild bees ${ }^{27,31,38}$ both at the inter and intraspecific levels. Our records were assigned to 172 BINs, 16 of which were new to BOLD. Of the 157 species reported in this study, only 67 of them had previously been barcoded from France. 
DNA barcoding using Sequel platform represents a helpful tool to process large numbers of bees to obtain not only species richness but also abundance data for further ecological analyses.

Our study revealed fourteen species with multiple BINs without morphological differentiation suggesting the existence of cryptic diversity. We have found a relatively high species richness of bees in urban areas. Our DNA barcode reference library will help to streamline the identification of wild bees and assess the impact of anthropogenic disturbances such as urbanization. Finally, it is a major contribution to the ultimate goal of completing the barcoding of all wild bee European fauna in a short time framework.

\section{Methods}

Field sampling. Wild bees (3532) were collected in 29 sites located in three cities of central France along alluvial areas of the Loire valley (Fig. 1, Table S1). The 30-year annual average temperature in our sampling area is $11.1^{\circ} \mathrm{C}$ with a minimum of $3.4^{\circ} \mathrm{C}$ in January and a maximum of $19.1^{\circ} \mathrm{C}$ in July. Average precipitation is $54.2 \mathrm{~mm}$ with a maximum of $64.3 \mathrm{~mm}$ in May (https://fr.climate-data.org).

The sampled material was collected over 2 years: in 2017 from April 11th till July 19th and in 2018 from April 23 rd to July 17 th (including Apis mellifera Linnaeus).

Bees were collected using a combination of pan-trapping and net sampling ${ }^{74}$.

Pan-traps Each of the 29 monitoring sites were equipped with yellow, blue and white UV-reflecting coloured plastic bowls ( $120 \mathrm{~mm}$ diameter $\times 120 \mathrm{~mm}$ height) and filled with $500 \mathrm{ml}$ of soapy water. The pan-traps were arranged in triplets; each triplet consisted of the three coloured bowls fixed to a wooden stick at the height of the vegetation ${ }^{75}$. In the 2017 season, two triplets were installed $100 \mathrm{~m}$ apart to each other at each site for an exposure time of $48 \mathrm{~h}$, repeated for five trapping sessions. In the 2018 season, the trapping time and the number of triplets were increased to enhance the sampling effort: three triplets spaced at $50 \mathrm{~m}$ apart were placed at each sampling site for an exposure time of $96 \mathrm{~h}$, repeated for five sessions. At the end of each trapping session, the traps were lifted and filtered. Bees were conserved in $96^{\circ}$ ethanol and stored in the freezer at $-20^{\circ} \mathrm{C}$ until identification.

Net sampling A butterfly net was used to ensure the sampling of individuals from genera such as Bombus and Colletes, known to be inefficiently captured with pan-traps ${ }^{74,75}$. Ten-minute capture sessions took place on $100 \mathrm{~m}$ transects, which corresponded to the distance between traps. We captured as many flower foraging individuals as possible during these sessions. In 2018, five net-sweeping sessions took place in each of the 29 sampling sites.

All 3532 collected bee specimens were pinned and imaged. We stored one hind leg of each individual on 96 well plates with $30 \mu \mathrm{L}$ of $96 \%$ ethanol in each well for DNA barcoding.

Morphological identifications were performed based on keys and published descriptions ${ }^{69,76-79}$.

Laboratory procedures and analyses of DNA barcoding data. Two methods were used to generate DNA barcodes.

Of the 214 samples 148 were DNA barcoded using standard Sanger sequencing at URZF INRAE Orléans. Total DNA was extracted from one hind leg using the NucleoSpin Tissue XS Genomic DNA Purification kit (Macherey-Nagel Inc.), following the manufacturer's protocol. The barcode fragment of mitochondrial cytochrome $c$ oxidase subunit I gene was first targeted with the standard primers LCO and $\mathrm{HCO}^{80}$. We ran PCR using Dream Taq Green DNA polymerase (Thermo Fisher Scientific) with a final concentration of $2.5 \mathrm{mM} \mathrm{MgCl} 2$ and $1 \mu \mathrm{M}$ for each primer and the following program: a starting denaturation step at $95^{\circ}$ for $3 \mathrm{~min}$, followed by five cycles of $95^{\circ} \mathrm{C}$ for $30 \mathrm{~s}, 47^{\circ} \mathrm{C}$ for $40 \mathrm{~s}$ and $72{ }^{\circ} \mathrm{C}$ for $60 \mathrm{~s}$, and $40 \mathrm{cycles}$ of $95^{\circ} \mathrm{C}$ for $30 \mathrm{~s}, 52^{\circ} \mathrm{C}$ for $40 \mathrm{~s}$ and $72^{\circ}$ for $60 \mathrm{~s}$, and a final extension step at $72^{\circ}$ for $5 \mathrm{~min}$. To amplify problematic taxa, two new primers were designed (Table S3) and used in combination with the following PCR program: a starting denaturation step at $95^{\circ}$ for $3 \mathrm{~min}$, followed by ten cycles of $95^{\circ} \mathrm{C}$ for $30 \mathrm{~s}, 59-50{ }^{\circ} \mathrm{C}\left(-1^{\circ} \mathrm{C}\right.$ per cycle) for $40 \mathrm{~s}$ and $72{ }^{\circ} \mathrm{C}$ for $60 \mathrm{~s}$, and 45 cycles of $95^{\circ} \mathrm{C}$ for $30 \mathrm{~s}, 56^{\circ} \mathrm{C}$ for $40 \mathrm{~s}$ and $72^{\circ}$ for $60 \mathrm{~s}$, and a final extension step at $72^{\circ} \mathrm{C}$ for $5 \mathrm{~min}$. Amplification was confirmed by agarose gel electrophoresis. PCR products were subsequently cleaned using the NucleoFast 96 PCR kit (Macherey-Nagel, Düren, Germany) and sequenced in both directions by the Sanger method using the ABI Prism BigDye Terminator v3.1 Cycle Sequencing Kit (Thermo Fisher Scientific). Sequencing reactions were purified by ethanol precipitation, loaded on an Applied Biosystems 3500 Genetic Analyzer (Thermo Fisher Scientific). We used CodonCode (CodonCode Corporation, Centerville, MA) for primers trimming, contig assembly and sequence editing. Sequence alignment was straightforward in the absence of indels and the sequences along with corresponding trace files were uploaded to the Barcode of Life Data Systems (BOLD) (http://www.barcodinglife.org) $)^{81}$.

A total of 3350 tissue samples (hind legs) were DNA barcoded using single-molecule real-time sequencing $\left(\mathrm{SMRT}^{49}\right)$ in the PacBio Sequel platform (Pacific Biosciences, Menlo Park, CA, USA) at the Canadian Centre for DNA Barcoding (CCDB), in the University of Guelph, Ontario, Canada).

Barcode DNA sequences were aligned in Geneious v.8.0.3 (www.geneious.com) through the MAFFT alignment tool ${ }^{82}$ to verify the correct $\operatorname{cox} 1$ codon translation into proteins and check for potential presence of numts by looking for stop codons, insertions and deletions, errors and inconsistencies. We edited SEQUEL sequences with minor errors caused by the addition or deletion of a single nucleotide that initiated a reading frame shift and the introduction of stop codons.

All sequences, along with the voucher data, images, and trace files, are deposited in BOLD and the sequences are deposited in GenBank (Table S2). All data are available from the BOLD database, https://doi.org/10.5883/ DS-BEECOI.

We used the Barcode Index Number system $(\mathrm{BIN})^{50}$ to delineate species using DNA barcode data. BINs were assigned automatically to each record with a barcode longer than $500 \mathrm{bp}$ based on the Refined Single Linkage (RESL) algorithm in BOLD 4. 
Sequence alignment generated by the amino acid-based (HMM) BOLD aligner was used to construct a Kimura 2 parameter ${ }^{83}$ (K2P) Neighbour-joining tree (File S1) to provide a graphic representation of the species divergence and calculate genetic intra and interspecific distances through the BOLD analytical tools support ${ }^{81}$. We constructed an approximately Maximum-Likelihood tree using Fast Tree 2 with default settings ${ }^{84}$ in Geneious v.8.0.3 (www.geneious.com) which was then used to represent species abundance, number of haplotypes and haplotype diversity values with the ITOL tree viewer ${ }^{85}$.

We used R ggplot $2^{86}$ to represent genetic intra and interspecific distances. Species boundaries were verified by comparing the maximum intraspecific distance and the distance to the nearest phylogenetic neighbour in the data set. The software DNAsp ${ }^{87}$ was used to calculate the number of haplotypes per species and the values of haplotype diversity ${ }^{88}$ when applicable (Table S4).

\section{Data availability}

Dataset title: POLLEN DNA barcode reference library. Resource link: https://doi.org/10.5883/DS-BEECOI. Number of data sets: (1) Data set name: DS-BEECOI. Data format: xml, tsv, fasta, ab1. Description: The POLLEN library dataset could be accessed through the Workbench platform of BOLD, and all data files can be downloaded from the BOLD public portal in different formats depending on the dataset type. All records are also accessible within BOLD, using the search function of the database. An excel spreadsheet containing the library dataset information is included (Table S5). Similarly, the fasta sequences of dataset barcodes are included as File S2. We compiled a checklist of the 157 species of bees found in our study (CL-BEE37 in BOLD) following the higher classification of TAXREF taxonomic repository.

Received: 29 September 2020; Accepted: 8 January 2021

Published online: 26 February 2021

\section{References}

1. Hallmann, C. A. et al. More than 75 percent decline over 27 years in total flying insect biomass in protected areas. PLoS ONE 12, e0185809 (2017).

2. Macgregor, C. J., Williams, J. H., Bell, J. R. \& Thomas, C. D. Moth biomass increases and decreases over 50 years in Britain. Nat. Ecol. Evol. 3, 1645-1649 (2019).

3. Sánchez-Bayo, F. \& Wyckhuys, K. A. G. Worldwide decline of the entomofauna: A review of its drivers. Biol. Conserv. 232, 8-27 (2019).

4. Thomas, C. D., Jones, T. H. \& Hartley, S. E. "Insectageddon": A call for more robust data and rigorous analyses. Glob. Chang. Biol. 25, 1891-1892 (2019).

5. van Klink, R. et al. Meta-analysis reveals declines in terrestrial but increases in freshwater insect abundances. Science (80-) 368, 417-420 (2020).

6. Potts, S. G. et al. Global pollinator declines: Trends, impacts and drivers. Trends Ecol. Evol. 25, 345-353 (2010).

7. Pérez-Méndez, N. et al. The economic cost of losing native pollinator species for orchard production. J. Appl. Ecol. 57, 599-608 (2020).

8. Porto, R. G. et al. Pollination ecosystem services: A comprehensive review of economic values, research funding and policy actions. Food Secur. 12, 1425-1442 (2020).

9. Winfree, R., Aguilar, R., Vázquez, D. P., LeBuhn, G. \& Aizen, M. A. A meta-analysis of bees’ responses to anthropogenic disturbance. Ecology 90, 2068-2076 (2009).

10. Godfray, H. C. J. et al. A restatement of the natural science evidence base concerning neonicotinoid insecticides and insect pollinators. Proc. R. Soc. B Biol. Sci. 281, 20140558 (2014).

11. Fortel, L. et al. Decreasing abundance, increasing diversity and changing structure of the Wild Bee Community (Hymenoptera: Anthophila) along an urbanization gradient. PLOS ONE 9, e104679 (2014).

12. Geslin, B. et al. The proportion of impervious surfaces at the landscape scale structures wild bee assemblages in a densely populated region. Ecol. Evol. 6, 6599-6615 (2016).

13. Geslin, B., Le Féon, V., Kuhlmann, M., Vaissière, B. E. \& Dajoz, I. The bee fauna of large parks in downtown Paris, France. Ann. la Société Entomol. Fr. 51, 487-493 (2015).

14. Baldock, K. C. R. et al. A systems approach reveals urban pollinator hotspots and conservation opportunities. Nat. Ecol. Evol. 3, 363-373 (2019).

15. Lerman, S. B., Contosta, A. R., Milam, J. \& Bang, C. To mow or to mow less: Lawn mowing frequency affects bee abundance and diversity in suburban yards. Biol. Conserv. 221, 160-174 (2018).

16. Kerr, J. T. et al. Climate change impacts on bumblebees converge across continents. Science 349, 177-180 (2015).

17. Soroye, P., Newbold, T. \& Kerr, J. Climate change contributes to widespread declines among bumble bees across continents. Science 367, 685-688 (2020).

18. McFrederick, Q. S. \& LeBuhn, G. Are urban parks refuges for bumble bees Bombus spp. (Hymenoptera: Apidae)?. Biol. Conserv. 129, 372-382 (2006).

19. Hall, D. M. et al. The city as a refuge for insect pollinators. Conserv. Biol. 31, 24-29 (2017).

20. Ropars, L., Dajoz, I. \& Geslin, B. La ville un désert pour les abeilles sauvages? J. Bot. Soc. Bot. Fr. 79, 29-35 (2017).

21. Falk, S. et al. Evaluating the ability of citizen scientists to identify bumblebee (Bombus) species. PLoS ONE 14, e0218614 (2019).

22. Bloom, E. H. \& Crowder, D. W. Promoting data collection in pollinator citizen science projects. Citiz. Sci. Theory Pract. 5(1), 3 https://doi.org/10.5334/cstp.217 (2020).

23. Levé, M., Baudry, E. \& Bessa-Gomes, C. Domestic gardens as favorable pollinator habitats in impervious landscapes. Sci. Total Environ. 647, 420-430 (2019).

24. Mason, L. \& Arathi, H. S. Assessing the efficacy of citizen scientists monitoring native bees in urban areas. Glob. Ecol. Conserv. 17, e00561 (2019).

25. Sheffield, C. S. et al. Contribution of DNA barcoding to the study of the bees (Hymenoptera: Apoidea) of Canada: Progress to date. Can. Entomol. 149, 736-754 (2017).

26. Sheffield, C. S., Hebert, P. D. N., Kevan, P. G. \& Packer, L. DNA barcoding a regional bee (Hymenoptera: Apoidea) fauna and its potential for ecological studies. Mol. Ecol. Resour. 9, 196-207 (2009).

27. Schmidt, S., Schmid-Egger, C., Morinière, J., Haszprunar, G. \& Hebert, P. D. N. DNA barcoding largely supports 250 years of classical taxonomy: Identifications for Central European bees (Hymenoptera, Apoidea partim ). Mol. Ecol. Resour. 15, 985-1000 (2015). 
28. Packer, L. \& Ruz, L. DNA barcoding the bees (Hymenoptera: Apoidea) of Chile: Species discovery in a reasonably well known bee fauna with the description of a new species of Lonchopria (Colletidae). Genome 60, 414-430 (2017).

29. Tang, M. et al. High-throughput monitoring of wild bee diversity and abundance via mitogenomics. Methods Ecol. Evol. 6, 1034$1043(2015)$.

30. Sonet, G. et al. Using next-generation sequencing to improve DNA barcoding: Lessons from a small-scale study of wild bee species (Hymenoptera, Halictidae). Apidologie 49, 671-685 (2018).

31. Creedy, T. J. et al. A validated workflow for rapid taxonomic assignment and monitoring of a national fauna of bees (Apiformes) using high throughput DNA barcoding. Mol. Ecol. Resour. 20, 40-53 (2020).

32. Gueuning, M. et al. Evaluating next-generation sequencing (NGS) methods for routine monitoring of wild bees: Metabarcoding, mitogenomics or NGS barcoding. Mol. Ecol. Resour. 19, 847-862 (2019).

33. Lanner, J., Curto, M., Pachinger, B., Neumüller, U. \& Meimberg, H. Illumina midi-barcodes: Quality proof and applications. Mitochondrial DNA Part A 30, 490-499 (2019).

34. González-Vaquero, R. A., Roig-Alsina, A. \& Packer, L. DNA barcoding as a useful tool in the systematic study of wild bees of the tribe Augochlorini (Hymenoptera: Halictidae). Genome 59, 889-898 (2016).

35. Gibbs, J. DNA barcoding a nightmare taxon: Assessing barcode index numbers and barcode gaps for sweat bees. Genome 61, 21-31 (2018).

36. Dorey, J. P., Schwarz, M. P. \& Stevens, M. I. Review of the bee genus Homalictus Cockerell (Hymenoptera: Halictidae) from Fiji with description of nine new species. Zootaxa 4674, 1-46 (2019).

37. Williams, P. H. et al. Unveiling cryptic species of the bumblebee subgenus Bombus s. str. worldwide with COI barcodes (Hymenoptera: Apidae). Syst. Biodivers. 10, 21-56 (2012).

38. Magnacca, K. N. \& Brown, M. J. F. DNA barcoding a regional fauna: Irish solitary bees. Mol. Ecol. Resour. 12, 990-998 (2012).

39. de Waard, J. R. et al. A reference library for Canadian invertebrates with 1.5 million barcodes, voucher specimens, and DNA samples. Sci. Data 6, 308 (2019).

40. Hua, F. et al. Opportunities for biodiversity gains under the world's largest reforestation programme. Nat. Commun. 7, 12717 (2016).

41. Gueuning, M., Frey, J. E. \& Praz, C. Ultraconserved yet informative for species delimitation: UCEs resolve long-standing systematic enigma in Central European bees. Mol. Ecol. Mec. https://doi.org/10.1111/mec.15629 (2020).

42. Phillips, J. D., French, S. H., Hanner, R. H. \& Gillis, D. J. HACSim: An R package to estimate intraspecific sample sizes for genetic diversity assessment using haplotype accumulation curves. PeerJ Comput. Sci. 6, e243 (2020).

43. Phillips, J. D., Gwiazdowski, R. A., Ashlock, D. \& Hanner, R. An exploration of sufficient sampling effort to describe intraspecific DNA barcode haplotype diversity: Examples from the ray-finned fishes (Chordata: Actinopterygii). DNA Barcodes 3(1), 66-73 (2015).

44. Phillips, J. D., Gillis, D. J. \& Hanner, R. H. Incomplete estimates of genetic diversity within species: Implications for DNA barcoding. Ecol. Evol. 9, 2996-3010 (2019).

45. Muséum national d'Histoire naturelle (ed). 2003-2020. Inventaire National du Patrimoine Naturel. https://inpn.mnhn.fr.

46. Zayed, A., Constantin, ŞA. \& Packer, L. Successful biological invasion despite a severe genetic load. PLoS ONE 2, e868 (2007).

47. Lecocq, T. et al. The alien's identity: Consequences of taxonomic status for the international bumblebee trade regulations. Biol. Conserv. 195, 169-176 (2016).

48. Danforth, B. N. Phylogeny of the bee genus Lasioglossum (Hymenoptera: Halictidae) based on mitochondrial COI sequence data. Syst. Entomol. 24, 377-393 (1999).

49. Hebert, P. D. N. et al. A Sequel to Sanger: Amplicon sequencing that scales. BMC Genom. 19, 219 (2018).

50. Ratnasingham, S. \& Hebert, P. D. N. A DNA-based registry for all animal species: The Barcode Index Number (BIN) system. PLoS ONE 8, e66213 (2013).

51. Carolan, J. C. et al. Colour patterns do not diagnose species: Quantitative evaluation of a DNA barcoded cryptic bumblebee complex. PLoS ONE 7, e29251 (2012).

52. Praz, C., Müller, A. \& Genoud, D. Hidden diversity in European bees: Andrena amieti sp. n., a new Alpine bee species related to Andrena bicolor (Fabricius, 1775) (Hymenoptera, Apoidea, Andrenidae). Alp. Entomol. 3, 11-38 (2019).

53. Pauly, A. Abeilles de Belgique et des régions limitrophes (Insecta: Hymenoptera: Apoidea) Famille Halictidae. (Institut royal des sciences naturelles de Belgique, 2019).

54. Gonçalves, R. B. \& Oliveira, P. S. Preliminary results of bowl trapping bees (Hymenoptera, Apoidea) in a southern Brazil forest fragment. J. Insect Biodivers. 1, 1-9 (2013).

55. Buri, P., Humbert, J.-Y. \& Arlettaz, R. Promoting pollinating insects in intensive agricultural matrices: Field-scale experimental manipulation of hay-meadow mowing regimes and its effects on bees. PLoS One 9(1), e85635 (2014).

56. Rhoades, P. et al. Sampling technique affects detection of habitat factors influencing wild bee communities. J. Insect Conserv. 21, 703-714 (2017).

57. Lettow, M. C. et al. Bee community responses to a gradient of oak savanna restoration practices. Restor. Ecol. 26, 882-890 (2018).

58. Onuferko, T. M., Skandalis, D. A., Cordero, R. L. \& Richards, M. H. Rapid initial recovery and long-term persistence of a bee community in a former landfill. Insect Conserv. Divers. 11, 88-99 (2018).

59. Geroff, R. K., Gibbs, J. \& McCravy, K. W. Assessing bee (Hymenoptera: Apoidea) diversity of an Illinois restored tallgrass prairie: Methodology and conservation considerations. J. Insect Conserv. 18, 951-964 (2014).

60. Griffin, S. R., Bruninga-Socolar, B., Kerr, M. A., Gibbs, J. \& Winfree, R. Wild bee community change over a 26-year chronosequence of restored tallgrass prairie. Restor. Ecol. 25, 650-660 (2017).

61. Ropars, L., Dajoz, I. \& Geslin, B. La diversité des abeilles parisiennes. Osmia 7, 14-19 (2018).

62. Portman, Z. M., Bruninga-Socolar, B. \& Cariveau, D. P. The state of bee monitoring in the United States: A call to refocus away from bowl traps and towards more effective methods. Ann. Entomol. Soc. Am. 113, 337-342 (2020).

63. Magnacca, K. N. \& Brown, M. J. Mitochondrial heteroplasmy and DNA barcoding in Hawaiian Hylaeus (Nesoprosopis) bees (Hymenoptera: Colletidae). BMC Evol. Biol. 10, 174 (2010).

64. Ballare, K. M. et al. Utilizing field collected insects for next generation sequencing: Effects of sampling, storage, and DNA extraction methods. Ecol. Evol. 9, 13690-13705 (2019).

65. Hill, G. E. Mitonuclear coevolution as the genesis of speciation and the mitochondrial DNA barcode gap. Ecol. Evol. 6, 5831-5842 (2016).

66. Ascher, J. S. \& Pickering, J. Life bee species guide and world checklist (Hymenoptera Apoidea Anthophila). http://www.discoverli fe.org/mp/20q? guide=Apoidea_species (2020).

67. LaBerge, W. E. A revision of the bees of the genus Andrena of the western hemisphere. Part XI. Minor subgenera and subgeneric key. Trans. Am. Entomol. Soc. 111, 441-567 (1985).

68. Warncke, K. Die Untergattungen der westpalaarktischen Bienengattung Andrena F. Memorias e Estud Muséu Zool. da Univ. Coimbra 307, 1-110 (1968).

69. Amiet, F., Herrmann, M., Müller, A. \& Neumeyer, R. Apidae 6: Andrena, Melitturga, Panurginus, Panurgus. Fauna Helv. 26, 1-317 (2010).

70. Michener, C. The bees of the world. (Johns Hopkins University Press, Baltimore, 2000).

71. Michener, C. D. The Social Behavior of the Bees: A Comparative Study (Harvard University Press, Cambridge, 1974). 
72. Pauly, A., Noël, G., Sonet, G., Notton, D. G. \& Boevé, J.-L. Integrative taxonomy resuscitates two species in the Lasioglossum villosulum complex (Kirby, 1802) (Hymenoptera: Apoidea: Halictidae). Eur. J. Taxon. 541 (2019).

73. Eberle, J., Ahrens, D., Mayer, C., Niehuis, O. \& Misof, B. A plea for standardized nuclear markers in metazoan DNA taxonomy. Trends Ecol. Evol. 35, 336-345 (2020).

74. Roulston, T. H., Smith, S. A. \& Brewster, A. L. A comparison of pan trap and intensive net sampling techniques for documenting a bee (Hymenoptera: Apiformes) Fauna. J. Kansas Entomol. Soc. 80, 179-181 (2007).

75. Westphal, C. et al. Measuring bee diversity in different European habitats and biogeographical regions. Ecol. Monogr. 78, 653-671 (2008).

76. Amiet, F., Herrmann, M., Müller, A. \& Neumeyer, R. Apidae 5: Ammobates, Ammobatoides, Anthophora, Biastes, Ceratina, Dasypoda, Epeoloides, Epeolus, Eucera, Macropis, Melecta, Melitta, Nomada, Pasites, Tetralonia, Thyreus, Xylocopa. Fauna Helv. 20, 1-356 (2007).

77. Amiet, F., Herrmann, M., Müller, A. \& Neumeyer, R. Apidae 2: Colletes, Dufourea, Hylaeus, Nomia, Nomioides, Rhophitoides, Rophites, Sphecodes, Systropha. Fauna Helv. 4, 1-239 (1999).

78. Amiet, F., Herrmann, M., Müller, A. \& Neumeyer, R. Apidae 3: Halictus, Lasioglossum. Fauna Helv. 6, 1-208 (2001).

79. Amiet, F., Herrmann, M., Müller, A. \& Neumeyer, R. Apidae 4: Anthidium, Chelostoma, Coelioxys, Dioxys, Heriades, Lithurgus, Megachile, Osmia, Stelis. Fauna Helv. 9, 1-273 (2004).

80. Folmer, O., Black, M., Hoeh, W., Lutz, R. \& Vrijenhoek, R. DNA primers for amplification of mitochondrial cytochrome c oxidase subunit I from diverse metazoan invertebrates. Mol. Mar. Biol. Biotechnol. 3, 294-299 (1994).

81. Ratnasingham, S. \& Hebert, P. D. N. BOLD: The barcode of life data system. Mol. Ecol. Notes 7, 355-364 (2007).

82. Katoh, K. MAFFT: A novel method for rapid multiple sequence alignment based on fast Fourier transform. Nucleic Acids Res. 30, 3059-3066 (2002).

83. Kimura, M. A simple method for estimating evolutionary rates of base substitutions through comparative studies of nucleotide sequences. J. Mol. Evol. 16, 111-120 (1980).

84. Price, M. N., Dehal, P. S. \& Arkin, A. P. FastTree 2-Approximately maximum-likelihood trees for large alignments. PLoS ONE 5, e9490 (2010).

85. Letunic, I. \& Bork, P. Interactive Tree Of Life (iTOL) v4: Recent updates and new developments. Nucleic Acids Res. 47, W256-W259 (2019).

86. Wickham, H. ggplot2 (Springer, New York, 2009). https://doi.org/10.1007/978-0-387-98141-3.

87. Rozas, J. et al. DnaSP 6: DNA sequence polymorphism analysis of large data sets. Mol. Biol. Evol. 34, 3299-3302 (2017).

88. Nei, M. Molecular evolutionary genetics (Columbia University Press, New York, 1987).

\section{Acknowledgements}

This work is part of the POLLEN project (2016-00108486) funded by the Region Centre Val de Loire (France). The authors are indebted to Carl Moliard and Xabier Pineau for technical assistance in the field and Jeremy Dewaard for providing useful information on taxon coverage of wild bee barcoding. We are thankful to students Sarah Flamans for DNA barcoding at URZF, Orléans; Henri Sacoura Cissé for curatorial work of the bee reference collection at IRBI, Tours and Anaïs Garnier, Baptiste Ducros, Juliette Carpentier and Alexia Briandon for help in bee collecting. We are very grateful to the entire team at the Canadian Centre for DNA Barcoding (Guelph, Canada), and in particular Evgeny Zakharov for his assistance with PacBio sequencing. We want to thank Christian Cocquempot for sharing with us its regional inventory of wild bees and Bernard Lemesle for his bibliographical contribution. This work is dedicated to the memory of Pr. Raphaël Boulay who conceived this project.

\section{Author contributions}

I.V. \& C.L.V. designed the study and wrote the first draft. Molecular lab work was carried out by I.V., B.C., R.L. Data barcode analyses were carried out by I.V.. Bee samples were identified morphologically by D.G., S.M. and I.V. Fieldwork was carried out by M.C., M.B., C.B., R.L. All authors read and approved the final manuscript.

\section{Competing interests}

The authors declare no competing interests.

\section{Additional information}

Supplementary Information The online version contains supplementary material available at https://doi. org/10.1038/s41598-021-83631-0.

Correspondence and requests for materials should be addressed to I.V.

Reprints and permissions information is available at www.nature.com/reprints.

Publisher's note Springer Nature remains neutral with regard to jurisdictional claims in published maps and institutional affiliations.

Open Access This article is licensed under a Creative Commons Attribution 4.0 International License, which permits use, sharing, adaptation, distribution and reproduction in any medium or format, as long as you give appropriate credit to the original author(s) and the source, provide a link to the Creative Commons licence, and indicate if changes were made. The images or other third party material in this article are included in the article's Creative Commons licence, unless indicated otherwise in a credit line to the material. If material is not included in the article's Creative Commons licence and your intended use is not permitted by statutory regulation or exceeds the permitted use, you will need to obtain permission directly from the copyright holder. To view a copy of this licence, visit http://creativecommons.org/licenses/by/4.0/.

(C) The Author(s) 2021 